\title{
Cumulative Adverse Event Reporting of Anaphylaxis After mRNA COVID-19 Vaccine (Pfizer-BioNTech) Injections in Japan: The First-Month Report
}

\author{
Toyotaka Iguchi ${ }^{1} \cdot$ Hikari Umeda $^{1} \cdot$ Michie Kojima $^{1} \cdot$ Yuri Kanno ${ }^{1} \cdot$ Yuta Tanaka ${ }^{1} \cdot$ Natsumi Kinoshita $^{1}$. \\ Daisaku Sato ${ }^{2}$
}

Accepted: 18 July 2021 / Published online: 4 August 2021

(c) The Author(s), under exclusive licence to Springer Nature Switzerland AG 2021

\begin{abstract}
Introduction In mid-February, the nationwide immunization plan for the prevention of coronavirus disease 2019 (COVID19) started in Japan (at first primarily focused on health professionals) using an mRNA-based vaccine (Pfizer/BioNTech). During the phase-in period from February to March, attention was focused on post-vaccination anaphylaxis and anaphylactoid symptoms from the viewpoint of ensuring the safety of the vaccination program.

Objective The aim of this report was to provide an update on the status of anaphylaxis and anaphylactoid symptoms occurring after vaccination for COVID-19, as reported under the Adverse Event Following Immunization (AEFI) reporting system in Japan.

Methods The Pharmaceutical and Medical Devices Agency (PMDA) received AEFI reports from health professionals and manufacturers under the reporting system for AEFI after vaccination for COVID-19, which has been in operation since midFebruary 2021. Reported AEFIs of anaphylaxis and anaphylactoid symptoms were assessed using the Brighton Collaboration Criteria to assess diagnostic certainty.

Results 1-month since Japan started the vaccination program for COVID-19 in February 2021, 578,835 doses have been administered to health professionals, with the PMDA receiving 181 suspected event reports of anaphylaxis and anaphylactoid symptoms. In 171 of these 181 cases, women developed these symptoms. Among 181 cases evaluated according to the Brighton Collaboration Criteria, 47 cases (26\%) were classified as level 1-3 (reporting rate: 8.1/100,000 doses).

Conclusion The results appear similar to reported AEFIs in foreign studies of coronavirus vaccine administration to health professionals, although the reporting rate was higher. Further work is needed to examine the causal relationship of anaphylaxis reactions to coronavirus vaccine administration. Issues of multiple reporting and possible sex/age bias also remain to be analyzed.
\end{abstract}

\section{Introduction}

On 14 February 2021, The Ministry of Health, Labour and Welfare (MHLW) granted Special Approval for Emergency for the first coronavirus vaccine-Comirnaty (Pfizer/BioNTech; hereinafter referred to as the 'mRNA-based vaccine') intramuscular injection-for the prevention of coronavirus

Daisaku Sato

sato-daisaku@pmda.go.jp

Office of Pharmacovigilance II, Pharmaceuticals and Medical Devices Agency, Tokyo, Japan

2 Center for Regulatory Science, Pharmaceuticals and Medical Devices Agency, Shin-Kasumigaseki Building, 3-3-2 Kasumigaseki, Chiyoda-ku, Tokyo 100-0013, Japan disease 2019 (COVID-19) in Japan. In mid-February, the nationwide immunization plan commenced, at first primarily focused on health professionals in the national hospital group network and other front-line hospitals. The program was expanded to other health professionals, followed by elderly populations, in May 2021. During the phase-in period from February to March, health professionals who initially received the vaccination were closely monitored for adverse events (AEs). In particular, anaphylaxis and anaphylactoid symptoms that developed after vaccinations were of high interest in terms of determining the safety of the vaccination.

The aim of this report was to update the status of anaphylaxis and anaphylactoid symptoms reported under the Adverse Event Following Immunization (AEFI) reporting 


\section{Keypoints}

In Japan, 1 month after starting the vaccination program using the mRNA coronavirus disease 2019 (COVID-19) vaccine (Pfizer-BioNTech), 578,835 doses have been administered. We provide an update of reported adverse events following immunization (AEFIs), focusing on anaphylaxis.

Forty-seven confirmed anaphylaxis cases were reported as AEFIs, corresponding to $8.1 / 100,000$ doses. This is a higher rate than seen with conventional vaccines but is similar to rates reported in foreign studies of the coronavirus vaccine.

system in Japan, in order to assess the need for further safety measures as the vaccination program is extended.

\section{Methods [Adverse Events Following Immunization (AEFI) Reporting System]}

The Pharmaceutical and Medical Devices Agency (PMDA) is the operational body that, after vaccinations, receives AEFI reports from health professionals and manufacturers under the Immunization Act and the Pharmaceuticals and Medical Devices Act. Health professionals are obliged to report AEFIs when they encounter cases of AEs after vaccination, in accordance with these Acts. Anaphylaxis and anaphylactoid symptoms were designated as serious AEFIs to be reported. AEFI reporting after vaccination for COVID-19 has been in operation since the emergency authorization in mid-February 2021. The number of administered doses was collected from the vaccination sites through the nationwide vaccine supply information network, the Vaccination Facilitation System (V-SYS) [1], operated by the MHLW, which was used as the denominator for calculating the frequency of AEFI reporting. The reported AEFIs were assessed by PMDA/MHLW medical experts. The Brighton Collaboration Criteria were applied to classify event reports of suspected anaphylaxis and anaphylactoid symptoms according to diagnostic certainty (level 1 is the highest certainty and level 5 is the lowest) [2]. The widely used Brighton Collaboration Criteria were helpful in enabling comparison between different studies.
For comparison, we also calculated the reporting ratio of anaphylaxis and anaphylactoid symptoms in the adult population (over 16 years of age) for influenza HA vaccines, from data in the PMDA's AE reporting database (JADAR) during the 5 seasons from 2015 to 2019 . The estimated total number of influenza HA vaccine doses over the five seasons was 262.48 million [3].

\section{Results (Suspected Anaphylaxis Reporting)}

As of 21 March 2021, 578,835 doses of the mRNA-based vaccine have been administered, and, to date, 733 (85 males [12\%], 647 females [88\%], 1 unknown [ $<1 \%$ ]) AEFIs have been reported from health care settings. Among these, there have been 181 (first dose: 177; second dose: 3; unknown: 1) suspected anaphylaxis reports [4], resulting in a reporting rate of 31.3/100,000 doses. In 171 of 181 cases, women developed suspected anaphylaxis and anaphylactoid symptoms. After 1 month of AEFI monitoring, the Committee on Drug Safety of the Pharmaceutical Affairs and Food Sanitation Council and the Vaccine Adverse Reaction Review Committee (hereinafter referred to as the 'Joint Committee') of the MHLW evaluated these cases using the Brighton Collaboration Criteria. Forty-seven of 181 (26\%) cases reported by 21 March were evaluated as levels $1-3$ cases (reporting rate: $8.1 / 100,000$ doses) (Table 1).

Thirty-five of the 47 cases (74\%) had a history of allergic disease or allergic reactions to medicines and/or food. In 44 of 47 cases (94\%), women developed anaphylaxis. The overall characteristics of reported anaphylaxis are summarized in Table 2.

\section{Discussion}

In a summary of Yellow Card reporting of the coronavirus vaccine, the British Medicines and Healthcare Products Regulatory Agency (MHRA) reported 215 cases of anaphylaxis and anaphylactoid symptoms after administration of 11.5 million vaccine doses (reporting rate: approximately $1.9 / 100,000$ doses) [5]. The experience in the UK is based mainly on adenovirus vaccine, and care is needed in comparing AEFIs of mRNA vaccines with those of adenovirus vaccines. Among mRNA vaccines, Shimabukuro et al. reported an anaphylaxis event rate of 0.47/100,000 doses for the Pfizer-BioNTech vaccine in the US, according to the Vaccine Adverse Event Reporting System (VAERS), during a 1-month period (14 December 2020-18 January 2021) [6]. 
Table 1 Confirmed anaphylaxis (Brighton level 1, 2 or 3) reaction reports after COVID-19 vaccination

\begin{tabular}{|c|c|c|c|c|c|c|c|c|c|}
\hline No. & Age (years) & Sex & Lot no. & $\begin{array}{l}\text { Onset after } \\
\text { vaccination } \\
(\operatorname{mins})^{b}\end{array}$ & $\begin{array}{l}\text { Background } \\
\text { history of } \\
\text { allergy }\end{array}$ & $\begin{array}{l}\text { Other possible } \\
\text { cause }\end{array}$ & $\begin{array}{l}\text { Evaluation of } \\
\text { the Brighton } \\
\text { collaboration } \\
\text { criteria }\end{array}$ & Treatment & $\begin{array}{l}\text { Treatment } \\
\text { outcome }\end{array}$ \\
\hline 1 & 36 & $\mathrm{~F}$ & EP2163 & 5 & $\begin{array}{c}\text { Bronchial } \\
\text { asthma }\end{array}$ & $\begin{array}{l}\text { Bronchial } \\
\text { asthma }\end{array}$ & 1 & $\begin{array}{l}\text { Adrenaline } \\
\text { Corticosteroid } \\
\text { SABA amino- } \\
\text { phylline }\end{array}$ & Recovering \\
\hline 2 & 24 & $\mathrm{~F}$ & EP2163 & 25 & - & None & 1 & Adrenaline & Recovered \\
\hline 3 & 29 & $\mathrm{~F}$ & EP9605 & 20 & Urticaria & Urticaria & 2 & Adrenaline & Recovered \\
\hline 4 & 52 & $\mathrm{~F}$ & EP2163 & 5 & $\begin{array}{l}\text { Bronchial } \\
\text { asthma, drug }\end{array}$ & None & 3 & Corticosteroid & Recovered \\
\hline 5 & 37 & $\mathrm{~F}$ & EP2163 & 22 & $\begin{array}{l}\text { Food, allergic } \\
\text { disease }\end{array}$ & Unknown & 2 & $\begin{array}{l}\text { Adrenaline } \\
\text { Corticosteroid } \\
\text { Anti-histaminic }\end{array}$ & Recovered \\
\hline 6 & 33 & $\mathrm{~F}$ & EP9605 & 5 & Animals & None & 2 & Adrenaline & Recovered \\
\hline 7 & 27 & $\mathrm{~F}$ & EP2163 & 30 & Food, drug & None & 2 & Adrenaline & Recovering \\
\hline 8 & 48 & $\mathrm{~F}$ & EP9605 & $\begin{array}{l}\text { Immediately } \\
\text { after vac- } \\
\text { cination } \\
(1 \text { min })\end{array}$ & - & None & 2 & $\begin{array}{l}\text { Adrenaline } \\
\text { Corticosteroid }\end{array}$ & Recovering \\
\hline 9 & 55 & $\mathrm{~F}$ & EP2163 & 10 & $\begin{array}{l}\text { Bronchial } \\
\text { asthma, ana- } \\
\text { phylaxis }\end{array}$ & None & 2 & $\begin{array}{l}\text { Corticosteroid } \\
\text { Anti-histaminic }\end{array}$ & Recovered \\
\hline 10 & 44 & $\mathrm{~F}$ & EP2163 second & 13 & Drug & None & 2 & Corticosteroid & Recovering \\
\hline 11 & 38 & $\mathrm{~F}$ & EP2163 & 3 & Urticaria & None & 2 & $\begin{array}{l}\text { Adrenaline } \\
\text { Anti-histaminic }\end{array}$ & Recovering \\
\hline 12 & 29 & $\mathrm{~F}$ & EP9605 & 29 & - & None & 3 & Unspecified & Recovered \\
\hline 13 & 51 & $\mathrm{~F}$ & EP2163 & 10 & - & Unknown & 2 & No information & Recovering \\
\hline 14 & 44 & $\mathrm{~F}$ & $\begin{array}{l}\text { EP2163 second } \\
\text { dose }\end{array}$ & 10 & - & None & 2 & $\begin{array}{l}\text { Adrenaline } \\
\text { Corticosteroid }\end{array}$ & Recovered \\
\hline 15 & 33 & $\mathrm{~F}$ & EP9605 & 30 & $\begin{array}{l}\text { Bronchial } \\
\text { asthma, drug }\end{array}$ & None & 2 & $\begin{array}{l}\text { Corticosteroid } \\
\text { Anti-histaminic }\end{array}$ & Recovering \\
\hline 16 & 55 & $\mathrm{~F}$ & EP9605 & 15 & Food, drug & None & 2 & No information & Recovered \\
\hline 17 & 50 & $\mathrm{~F}$ & EP9605 & 9 & Allergic disease & None & 2 & $\begin{array}{l}\text { Adrenaline } \\
\text { Corticosteroid } \\
\text { Anti-histaminic }\end{array}$ & No information \\
\hline 18 & 34 & $\mathrm{~F}$ & EP9605 & 5 & - & None & 2 & $\begin{array}{l}\text { Adrenaline } \\
\text { Anti-histaminic }\end{array}$ & Recovering \\
\hline 19 & 42 & $\mathrm{~F}$ & EP9605 & 7 & Food, pollen & None & 3 & $\begin{array}{l}\text { Adrenaline } \\
\text { Corticosteroid } \\
\text { Anti-histaminic } \\
\text { SABA }\end{array}$ & Unrecovered $^{\mathrm{a}}$ \\
\hline 20 & 37 & $\mathrm{~F}$ & EP9605 & 3 & Food, drug & Unknown & 2 & $\begin{array}{l}\text { Steroid } \\
\text { Anti-histaminic }\end{array}$ & Recovered \\
\hline 21 & 43 & $\mathrm{~F}$ & EP9605 & 5 & Food, drug & None & 2 & $\begin{array}{l}\text { Adrenaline } \\
\text { Corticosteroid }\end{array}$ & Recovered \\
\hline 22 & 35 & $\mathrm{~F}$ & EP9605 & 13 & - & Unknown & 2 & Anti-histaminic & Recovering \\
\hline 23 & 24 & $\mathrm{~F}$ & EP9605 & 10 & $\begin{array}{l}\text { Bronchial } \\
\text { asthma, } \\
\text { animals, } \\
\text { house dust }\end{array}$ & None & 2 & $\begin{array}{l}\text { Corticosteroid } \\
\text { Anti-histaminic }\end{array}$ & Recovering \\
\hline 24 & 46 & $\mathrm{~F}$ & EP9605 & 13 & Food & None & 2 & Corticosteroid & Recovering \\
\hline 25 & 50 & $\mathrm{~F}$ & EP9605 & 15 & Urticaria & None & 1 & Corticosteroid & Recovering \\
\hline 26 & 49 & $\mathrm{~F}$ & EP9605 & 10 & $\begin{array}{c}\text { Bronchial } \\
\text { asthma }\end{array}$ & Unknown & 1 & $\begin{array}{l}\text { Adrenaline } \\
\text { Corticosteroid } \\
\text { Anti-histaminic }\end{array}$ & Recovering \\
\hline
\end{tabular}


Table 1 (continued)

\begin{tabular}{|c|c|c|c|c|c|c|c|c|c|}
\hline No. & Age (years) & Sex & Lot no. & $\begin{array}{l}\text { Onset after } \\
\text { vaccination } \\
(\text { mins })^{b}\end{array}$ & $\begin{array}{l}\text { Background } \\
\text { history of } \\
\text { allergy }\end{array}$ & $\begin{array}{l}\text { Other possible } \\
\text { cause }\end{array}$ & $\begin{array}{l}\text { Evaluation of } \\
\text { the Brighton } \\
\text { collaboration } \\
\text { criteria }\end{array}$ & Treatment & $\begin{array}{l}\text { Treatment } \\
\text { outcome }\end{array}$ \\
\hline 27 & 44 & $\mathrm{~F}$ & EP9605 & 10 & Food & None & 2 & $\begin{array}{l}\text { Corticosteroid } \\
\text { Anti-histaminic }\end{array}$ & Recovering \\
\hline 28 & 24 & M & EP9605 & 10 & Food, pollen & None & 3 & $\begin{array}{l}\text { Corticosteroid } \\
\text { Anti-histaminic }\end{array}$ & Recovering \\
\hline 29 & 22 & M & EP9605 & 15 & - & None & 2 & $\begin{array}{l}\text { Corticosteroid } \\
\text { Anti-histaminic }\end{array}$ & Recovered \\
\hline 30 & 26 & $\mathrm{~F}$ & EP2163 & 5 & - & None & 2 & $\begin{array}{l}\text { Corticosteroid } \\
\text { Anti-histaminic }\end{array}$ & Recovering \\
\hline 31 & 39 & $\mathrm{~F}$ & EP9605 & 7 & Drug & Menstruation & 3 & No information & Recovering \\
\hline 32 & 38 & $\mathrm{~F}$ & EP9605 & 15 & $\begin{array}{l}\text { Bronchial } \\
\text { asthma, food, } \\
\text { metal }\end{array}$ & None & 2 & $\begin{array}{l}\text { Corticosteroid } \\
\text { Anti-histaminic }\end{array}$ & Recovered \\
\hline 33 & 25 & $\mathrm{~F}$ & EP9605 & 50 & - & $\begin{array}{l}\text { Chronic ton- } \\
\text { silitis }\end{array}$ & 1 & $\begin{array}{l}\text { Adrenaline } \\
\text { Anti-histaminic }\end{array}$ & Recovered \\
\hline 34 & 55 & $\mathrm{~F}$ & EP9605 & 480 & Drug & None & 2 & $\begin{array}{l}\text { Corticosteroid } \\
\text { Anti-histaminic }\end{array}$ & Recovering \\
\hline 35 & 48 & $\mathrm{~F}$ & EP9605 & 30 & - & None & 2 & No information & Recovered \\
\hline 36 & 43 & $\mathrm{~F}$ & EP9605 & 5 & Drug, pollen & None & 2 & $\begin{array}{l}\text { Adrenaline } \\
\text { Corticosteroid } \\
\text { Anti-histaminic }\end{array}$ & Recovered \\
\hline 37 & 42 & $\mathrm{~F}$ & EP9605 & 10 & Pollen & Unknown & 3 & Anti-histaminic & Recovering \\
\hline 38 & 50 & $\mathrm{~F}$ & EP9605 & 20 & Drug & None & 2 & $\begin{array}{l}\text { Adrenaline } \\
\text { Corticosteroid }\end{array}$ & Recovered \\
\hline 39 & 42 & $\mathrm{~F}$ & EP2163 & 20 & $\begin{array}{l}\text { Drug, food, } \\
\text { cosmet- } \\
\text { ics, allergic } \\
\text { disease }\end{array}$ & None & 1 & Adrenaline & Recovering \\
\hline 40 & 24 & M & EP9605 & 30 & Food, pollen & None & 2 & Anti-histaminic & Recovered \\
\hline 41 & 37 & $\mathrm{~F}$ & $\begin{array}{l}\text { EP2163 second } \\
\text { dose }\end{array}$ & 2 & Drug & None & 2 & $\begin{array}{l}\text { Corticosteroid } \\
\text { Anti-histaminic }\end{array}$ & Unrecovered $^{\mathrm{a}}$ \\
\hline 42 & 38 & $\mathrm{~F}$ & EP9605 & 230 & $\begin{array}{l}\text { Bronchial } \\
\text { asthma }\end{array}$ & None & 2 & $\begin{array}{l}\text { Adrenaline } \\
\text { Corticosteroid } \\
\text { SABA }\end{array}$ & Recovered \\
\hline 43 & 54 & $\mathrm{~F}$ & EP9605 & 40 & $\begin{array}{l}\text { Bronchial } \\
\text { asthma, drug }\end{array}$ & None & 2 & $\begin{array}{l}\text { Adrenaline } \\
\text { Anti-histaminic }\end{array}$ & Recovered \\
\hline 44 & 56 & $\mathrm{~F}$ & EP9605 & 60 & $\begin{array}{l}\text { Bronchial } \\
\text { asthma }\end{array}$ & None & 1 & $\begin{array}{l}\text { Corticosteroid } \\
\text { Anti-histaminic } \\
\text { Aminophylline }\end{array}$ & Recovering \\
\hline 45 & 41 & $\mathrm{~F}$ & EP9605 & 10 & $\begin{array}{l}\text { Bronchial } \\
\text { asthma, drug, } \\
\text { pollen }\end{array}$ & None & 2 & $\begin{array}{l}\text { Adrenaline } \\
\text { Corticosteroid } \\
\text { Anti-histaminic }\end{array}$ & Recovering \\
\hline 46 & 31 & $\mathrm{~F}$ & EP9605 & 5 & - & Unknown & 3 & Anti-histaminic & Recovered \\
\hline 47 & 47 & $\mathrm{~F}$ & EP2163 & 20 & $\begin{array}{l}\text { Urticaria, food, } \\
\text { drug }\end{array}$ & None & 2 & Anti-histaminic & Recovered \\
\hline
\end{tabular}

COVID-19 coronavirus disease 2019, $F$ female, $M$ male, $S A B A$ short-acting $\beta$-agonists

${ }^{a}$ These cases were reported by 21 March 2021 and were evaluated for Brighton Collaboration Criteria by 25 March 2021

bonset after vaccination' includes estimates of elapsed time before onset for cases where the exact time was not recorded

${ }^{\mathrm{c}}$ The Brighton Collaboration Criteria are used to define the level of diagnostic certainty of reported cases of anaphylaxis and anaphylactoid symptoms, based on combinations of symptoms. Level 1 is the highest level of diagnostic certainty. Levels 4 and 5 do not meet the Brighton Collaboration Criteria definition of anaphylaxis

${ }^{\mathrm{d}}$ Most cases received treatments (adrenaline and/or corticosteroid and/or anti-histaminic drug) in a hospital after the onset of anaphylaxis, and had recovered or been recovering by the cut-off date 
Table 2 Characteristics of reported anaphylaxis (Brighton level 1, 2 or 3) after COVID-19 vaccination in Japan (14 February-21 March 2021)

\begin{tabular}{ll}
\hline Characteristics & No. of cases $(\%)[n=47]$ \\
\hline Age, years [median (range)] & $41(22-56)$ \\
Female sex & $44(94)$ \\
Time to onset, min [median (range)] & $10(<1-480)$ \\
Symptom onset, min & \\
$\leq 5$ & $30(64)$ \\
$\leq 30$ & $41(87)$ \\
$>30$ & $6(13)$ \\
Prior allergic history & \\
Allergies and allergic reaction to food, & $34(72)$ \\
$\quad$ drug, pollen, animals & $1(2)$ \\
Prior anaphylaxis & \\
Vaccine doses & 45 \\
First & 2 \\
Second & \\
Brighton level & $7(15)$ \\
1 & $33(70)$ \\
2 & $7(15)$ \\
3 & $8.1 / 100,000$ \\
Anaphylaxis reporting rate &
\end{tabular}

Data are expressed as $n(\%)$ unless otherwise specified

COVID-19 coronavirus disease 2019

We have also reviewed the records of suspected anaphylaxis and anaphylactoid symptoms reported in the past for comparable influenza HA vaccines. Over the last 5 seasons (2015-2019), the reported number of suspected anaphylaxis and allergy-related reactions was 56 , corresponding to a rate of 0.02/100,000 doses, in the PMDA's JADER database (electronic supplementary material). The most frequent rate of suspected anaphylaxis reporting for influenza HA vaccine was 1.0/100,000 doses in the 2009 season (H1N1) [7]. Among 118 cases of suspected anaphylaxis, 55 (46.8\%) were level 1-3 according to the Brighton Collaboration Criteria.

In the $2009 \mathrm{H} 1 \mathrm{~N} 1$ influenza vaccinations, the rate of female cases with suspected anaphylaxis was around $75 \%$ of the total, which is similar to the rate of development in women over the last 5 seasons of reporting after influenza vaccinations. Thus, the trend for a higher rate of reporting of anaphylaxis and anaphylactoid symptoms in women in the adult population after the influenza vaccination also appears to be the case for the COVID-19 vaccination in Japan.

The current Japanese rate of anaphylaxis and anaphylactoid symptom reporting $(8.1 / 100,000$ doses) [level 1-3 according to the Brighton Collaboration Criteria] seems relatively high. Multiple factors may be potentially associated with this high reporting rate. For example, the vaccinees were health professionals who were closely monitored and who were requested to report AEFIs. For comparison,
Blumenthal et al. demonstrated that Mass General Brigham employees who received their first dose of a COVID-19 vaccine developed anaphylaxis at a rate of 25/100,000 doses [8]. There could also be other relevant factors, such as reporting bias, differences in the demography of the vaccinee population, etc. The possibility of anaphylaxis has been highly publicized in the context of the attention given to coronavirus vaccines by the media. We found that female cases accounted for $88 \%$ of the 733 AEFI reports, and the median age of cases reporting anaphylaxis AEFIs was 41 years, but these findings may simply reflect the demography of the vaccinee population.

The MHLW has been warning health professionals to exercise caution in the case of vaccinees who have a previous medical history of systemic allergic reactions, including anaphylaxis, allergy, or severe sensitivities to any vaccine, food, etc. [9]. When the vaccination program started, the joint committee of the MHLW recommended that for those who had encountered severe allergic symptoms in the past, including anaphylaxis, follow-up after vaccinations should be performed for $30 \mathrm{~min}$, while for others, follow-up should be performed for at least $15 \mathrm{~min}$ [10].

\section{Conclusion}

One month after Japan started the vaccination program for COVID-19 in February 2021, 578,835 doses had been administered to health professionals. Among 181 AEFI cases of anaphylaxis and anaphylactoid symptoms evaluated according to the Brighton Collaboration criteria, 47 cases $(26 \%)$ were classified as level 1-3 (reporting rate: $8.1 / 100,000$ doses), which is similar to those AEFIs reported in foreign studies of coronavirus vaccine administration to health professionals, but higher than the rates reported for conventional scheduled vaccines.

Further work is needed to examine the causal relationship of anaphylaxis reactions to administration of the coronavirus vaccine. Furthermore, the issues of multiple reporting and reporting sex/age bias also remain to be analyzed. In addition, to date, only one type of coronavirus vaccine is available in Japan, therefore the comparison of AEFI reporting rates among different types of coronavirus vaccines will be a challenge for the future. At this point, we are not able to conclude that the characteristics of AEFI reporting of the coronavirus vaccine are different from those of other vaccines available on the market; however, they will be further assessed on the basis of the accumulation of AEFI reports in Japan and from the rest of the world.

We need to continue close monitoring of the reporting trend of suspected anaphylaxis and anaphylactoid symptom cases after vaccinations, as the target populations of vaccination were shifted from health professionals to the elderly 
population in May 2021. The PMDA, in collaboration with the MHLW, will be regularly publishing the cumulative results of event reporting.

Supplementary Information The online version contains supplementary material available at https://doi.org/10.1007/s40264-021-01104-9.

Acknowledgements The opinions expressed in this article are those of the authors and do not necessarily reflect the official position of the PMDA.

\section{Declarations}

Funding No funding was received for this research.

Conflict of Interest Toyotaka Iguchi, Hikari Umeda, Michie Kojima, Yuri Kanno, Yuta Tanaka, Natsumi Kinoshita, and Daisaku Sato declare no competing interests.

Ethics Approval Not applicable (waived by the Ethics Committee of the PMDA).

Consent to Participate Not applicable. All data are publicly available from the MHLW and PMDA websites.

Consent for Publication Not applicable. All data are publicly available from the MHLW and PMDA websites. All authors approved publication of this article.

Availability of Data and Material Available from the MHLW and PMDA websites.

Code Availability Not applicable.

Author Contributions HU, MK, NK, YK, and YT handled and analyzed the data. TI and DS wrote the manuscript. All authors read and approved the final version.

\section{References}

1. Ministry of Health, Labour and Welfare. About Vaccination Facilitation System (V-SYS). Updated December 2020. 2021. https:// www.mhlw.go.jp/content/10906000/000707430.pdf. Accessed 3 Jun 2021.

2. Rüggeberg JU, Gold MS, Bayas JM, et al.; Brighton Collaboration Anaphylaxis Working Group. Anaphylaxis: case definition and guidelines for data collection, analysis, and presentation of immunization safety data. Vaccine. 2007;25(31):5675-84. https:// doi.org/10.1016/j.vaccine.2007.02.064.

3. Pharmaceutical and Medical Devices Agency. The Japanese Adverse Drug Event Reporting Data Base. 2021. https://www. pmda.go.jp/safety/info-services/drugs/adr-info/suspected-adr/ 0003.html. Accessed 29 March 2021.

4. Ministry of Health, Labour and Welfare. Report of Anaphylaxis Reactions. Updated 26 March 2021. 2021. https://www.mhlw.go. jp/content/10906000/000759517.pdf. Accessed 29 Mar 2021.

5. Medicines and Healthcare Products Regulatory Agency (MHRA), UK. Coronavirus vaccine-weekly summary of Yellow Card reporting. Updated March 2021. 2021. https://www.gov.uk/gover nment/publications/coronavirus-covid-19-vaccine-adverse-react ions/coronavirus-vaccine-summary-of-yellow-card-reporting. Accessed 29 Mar 2021

6. Shimabukuro TT, Cole M, Su JR. Reports of anaphylaxis after receipt of mRNA COVID-19 Vaccines in the US-December 14, 2020-January 18, 2021. JAMA. 2021;325(11):1101-2. https:// doi.org/10.1001/jama2021.1967.

7. Ministry of Health, Labour and Welfare. Report of Anaphylaxis Reactions. Updated August, 2010. 2010. https://www.mhlw.go. $\mathrm{jp} / \mathrm{stf} 2 /$ shingi2/2r9852000000n6tv-att/2r9852000000n7j8.pdf. Accessed 29 Mar 2021.

8. Blumenthal KG, Robinson LB, Camargo CA, et al. Acute Allergic Reactions to mRNA COVID-19 Vaccines. JAMA. 2021;325(15):1562-5. https://doi.org/10.1001/jama.2021.3976.

9. Pharmaceutical and Medical Devices Agency. Labelling of Comirnaty. Updated February 2021. 2021. https://www.pmda. go.jp/drugs/2021/P20210212001/672212000_30300AMX00231_ B101_1.pdf. Accessed 29 Mar 2021.

10. Ministry of Health, Labour and Welfare. Vaccine Committee Documents. Updated February 2021. 2021.https://www.mhlw.go.jp/ stf/shingi2/0000192554_00004.html. Accessed 29 Mar 2021. 